\title{
Invasive carnivores in Patagonia: defining priorities for their management using the American mink (Neovison vison) as a case study
}

\author{
Laura Fasola ${ }^{1, \otimes}$ \& Alejandro Eduardo Jorge ValenZuela ${ }^{2}$ \\ 1. Centro Austral de Investigaciones Científicas, CADIC-CONICET, Ushuaia, Argentina. 2. Coordinación Patagonia Austral, \\ Administración de Parques Nacionales, Ushuaia, Argentina.
}

\begin{abstract}
Aвstract. The American mink is a widespread invasive carnivore in Patagonia, and due to its foraging behavior that allows it to exploit a wide variety of prey, it is the exotic carnivore with the highest potential impact on the region's biodiversity. Available regional information on mink presence/absence, as well as abundance estimations, is scarce even though it is vital to plan management actions. Here, we integrate the confirmed distribution of mink in Patagonia with its potential presence for areas where information is lacking, based on the location of animal releases and estimated dispersal rates. We propose an Area Prioritization Tool (APT) for invasive species management by overlapping habitat suitability, current known range, colonization fronts and areas deemed important for biodiversity conservation. Among the prioritized areas, we selected three and suggested a Protocol for Eradication Tasks (PET), based on successful mink eradication experiences in Europe. Finally, we estimated the relative costs associated with the PET's implementation in each area. We present this work as a systematic, applied tool to show a feasible way to face the invasive species problems in Patagonia and their management.
\end{abstract}

[Keywords: area prioritization tool, Argentina, biological invasions, predation, important bird areas, protocol for mink eradication]

\begin{abstract}
Resumen. Carnívoros invasores en Patagonia: Definiendo prioridades para su manejo usando el visón americano (Neovison vison) como caso de estudio: El visón Americano es una especie introducida con una amplia distribución en Patagonia y por su comportamiento de forrajeo es el carnívoro invasor con el mayor potencial para afectar a la biodiversidad en la región. La información disponible acerca de la presencia/ ausencia del visón en la región y de estimaciones poblacionales es muy escasa aun cuando esto es vital para la planificación de acciones de manejo. En este trabajo integramos la información disponible acerca de la presencia del visón hasta la fecha y evaluamos su presencia en sitios donde hay vacíos de información, basándonos en la ubicación de los puntos de liberación de individuos, distribución confirmada y estimaciones de la capacidad de dispersión. Proponemos una Herramienta de Priorización de Áreas (HPA) para definir sitios prioritarios para el manejo, superponiendo mapas de distribución de la especie, de hábitat adecuado y de áreas de importancia para la conservación de la biodiversidad. Entre las áreas prioritarias, seleccionamos tres y sugerimos un Protocolo de Tareas de Erradicación (PTE) como estrategia de manejo del visón americano, basado en experiencias de erradicación Europeas exitosas. Finalmente, estimamos costos relativos asociados a la implementación de tal PTE en cada una de las áreas seleccionadas. Presentamos este trabajo como una herramienta aplicada, enfocada en mostrar una forma simplificada para afrontar el problema de las especies invasoras en Patagonia y su manejo.
\end{abstract}

[Palabras clave: áreas importantes para la conservación de aves, Argentina, herramienta para la priorización de áreas, impacto por depredación, invasiones biológicas, protocolo de acciones para la erradicación del visón]

\section{INTRODUCTION}

The human-mediated redistribution of species around the globe is creating a world without natural barriers, which used to shelter original ecosystems from biota immigration (Mack et al. 2000). Once alien species succeed in the novel ecosystem, they may drive native species to extinction, which is irreversible and considered the second most important humancaused driver of global biodiversity loss (Vitousek et al. 1997). As developing countries in the global South tend to have larger and more diverse natural habitats than richer ones in the North, management strategies to control invasions applied in developing countries could be very important for global biodiversity conservation (Nuñez \& Pauchard 2010). However, research on biological invasions is still strongly biased towards developed nations, where the available knowledge of basic scientific knowledge of natural ecosystems is greater (Nuñez \& Pauchard 2010). But, how much information on invasive species populations do we need 
to gather before managing them? Simberloff (2003) has pointed that accurate biological knowledge may not be essential for success in preventing or eradicating an alien species but that rapid action is.

Argentinean Patagonia is a vast, lowly populated region where various invasive carnivores have been introduced with different objectives and have succeeded in the wild. While feral dogs and cats are directly associated with and are a consequence of human activities, other wild carnivores include the grey fox (Pseudalopex griseus), which was introduced to Tierra del Fuego Island from the mainland in 1950's as a biological control agent against the growing population of exotic European rabbits (Oryctolagus cuniculus; Jaksic \& Yanez 1983), and the American mink (Neovison vison), which was introduced to the region for fur farming (Jaksic et al. 2002).

Specifically regarding the mink, in the 1930s the Argentinean Ministry of Agriculture promoted fur farming initiatives, to diversify rural economic activities. During the 1940's, American mink farms opened in several Patagonian provinces (Godoy 1963; GarcíaMata 1982) and remained in operation until the 1970's (Pagnoni et al. 1986; Jaksic et al. 2002). Mink were intentionally released or escaped from farms, and by the mid-1970's, their effects on native fauna were apparent and some local attempts to control them began (Foerster 1973). Currently, it is widespread across the region, distributed along the Andes Mountain Range from $39^{\circ} \mathrm{S}$ (Neuquén Province) to $50^{\circ} \mathrm{S}$ (Santa Cruz Province) (Fasola et al. 2011; Fasola and Roesler unpublished data) and throughout most of the Tierra del Fuego Archipelago (Fasola et al. 2011; Valenzuela et al. 2014). The mink is known worldwide for its negative effects on native fauna via predation (Macdonald \& Harrington 2003), particularly, for its effects on prey species that are already threatened and find in this fierce predator a toboggan towards extinction (e.g., watervole Arvícola terrestris, Macdonald \& Stratchan 1999; European mink, Mustela lutreola, Macdonald et al. 2002). Mink are still expanding in Patagonia, which raises concerns for regional biodiversity conservation, especially for birds (Peris et al. 2009; Macdonald \& Harrington 2003; Roesler et al. 2012b; Maley et al. 2011; Petracci et al. 2013; Mazar Barnett et al. 2013). The stoat (Mustela erminea), another mustelid species, similar to mink and with similar impact to native New Zealand fauna is considered one of the 100 World's Worst Invasive Alien Species (Lowe et al. 2000). Furthermore, experiences elsewhere have demonstrated that after mink removal, threatened prey species have shown positive and rapid responses to management actions (Nordstrom et al. 2003; Harrington et al. 2009).

At the same time, wildlife managers have expressed the importance of accessing relevant scientific information for an appropriate planning of exotic species management strategies (Sanguinetti et al. 2014). This article has two objectives attending managers' needs. First, it lays out the design for a relatively quick and simple science-based tool (Area Prioritation tool: APT) to prioritize zones for exotic wildlife management actions, using primary information on the specific species (habitat preferences, spatial distribution) and knowledge of the conservation value of different areas. For this exercise, we take the American mink in Patagonia as a study case, but the process has a general applicability to other species. Second, we develop a protocol of eradication tasks (Protocol of Eradication Tasks: PET) from three priority areas with American mink. This PET is meant to be a management aide to allow authorities to prepare budgets for fundraising and begin adaptive management for invasive species.

\section{METHODS}

\section{Study Area}

The area encompasses the Argentinean provinces of Neuquén, Río Negro, Chubut, Santa Cruz and Tierra del Fuego, Antártida e Islas del Atlántico Sur, which have a combined surface area of $786,575 \mathrm{~km}^{2}$. There are three eco-regions in Patagonia (Burkart et al. 1999). The Argentine monte (part of Neuquén, Río Negro and Chubut), where xeric shrublands are the typical vegetation cover, accompanied by an important proportion of bare ground. Annual precipitation ranges between 80 to $200 \mathrm{~mm}$ and concentrates in the colder months. The Patagonian steppe (west of Neuquén and Río Negro, most of Chubut and Santa Cruz and north of Tierra del Fuego) is the largest eco-region in Patagonia (>80 $\%)$ and is dominated by shrubs and herbs. The weather is temperate-cold and dry with constant strong winds from the west and snow in winter. Annual precipitation decreases from west to east (500 mm to 250-100 mm, Cabrera 1971). The third eco-region is the Andean Patagonian forest (a thin strip along the Andes on the western side of Río Negro, Chubut and Santa Cruz, the southwest of Neuquén and the south-southwest of Tierra del 
Fuego), dominated by Nothofagus spp. The climate is cold-temperate and humid, with precipitations (including abundant snow) during winter and spring. Precipitation decreases from the Andes towards its limit in the steppe $(4000 \mathrm{~mm}$ to 800 $\mathrm{mm})$ (Cabrera 1971).

\section{Target species for control-eradication actions}

The American mink is a semiaquatic generalist carnivore, living on small mammals, birds, crustaceans and fish as main prey types in Patagonia (Fasola et al. 2011, Valenzuela et al. 2013a) while it can take lizards, amphibians and small crustaceans (e.g. amphipods) when locally abundant (Roesler unpublished data). It is a solitary animal but pairs or families can be encountered occasionally during mating season (winter) and rearing time (summer) respectively. Spatially, mink individuals overlap home ranges, though intersexual overlap is greater than the intra-sexual one (Harrington \& Macdonald 2008). The mink shows a strong association to waterland interfaces, where it concentrates its activity within the first $50 \mathrm{~m}$ from the water (Harrington \& Macdonald 2008). Thus, shorelines are considered a prerequisite for mink becoming resident at a site (Iordan et al. 2012). Mink records in Argentina indicate that it can occupy the two main Patagonian habitats (Andean forest and steppe), as well as the eco-tone between them (Fasola et al. 2011).

\section{Area Prioritization Tool (APT) for exotic species management: American mink in Patagonia}

The APT (Figure 1) was built following the rationale of the Analytic Hierarchy Process (Saaty 2008), which is useful to reduce a complex multicriterion decision-making task by structuring the goal (a major decision) into its component parts and giving relative weights to the different decision criteria (see Skurka Darin et al. 2011). This decision schedule, relying more on relative importance of attributes than on precise measurements (Saaty 2008), was applied in this case to give a management priority level to a set of sub-areas within the region. Therefore, our APT is a spatial arrangement showing the distribution of priority for management at a regional level, based on primary, georeferenced information of target species for control (habitat preferences, spatial distribution, invasion rate, etc.), and the conservation value of different zones within the considered area (threatened species distribution, protected areas, highly bio-diverse areas, etc.).

We then applied the APT for the mink in Patagonia to test the tool and to determine a map of priority areas where efforts for this species' management should focus. This APT is based on the following geographically referenced primary information: (i) a map of habitat suitability plus a distribution map for the mink, and (ii) a conservation map built using Important Bird Areas (Di Giacomo et al. 2007). Due to the well documented impact of mink on bird populations (Macdonald \& Harrington 2003), we chose the Important Bird Areas map as our base layer for the conservation map, recognizing that these areas are themselves a prioritization tool applied to bird conservation, developed by BirdLife International based on information about threatened, endemic and important concentration of species of birds.

The area of Argentinean Patagonia (ca. 787,100 $\mathrm{km}^{2}$ ) was split into a $2,500 \mathrm{~km}^{2}$ size cells (sub-areas, $50 \mathrm{~km} \times 50 \mathrm{~km}$ ) grid, following the Otter National Survey in England (Crawford 2010), which is also the basis for the U.K. mink survey (cells with less than $15 \%$ overlapping Patagonian area where discarded). We combined the information from a habitat suitability-distribution map with a conservation map to build the final map of priority mink management areas in Patagonia. The habitat suitability map was created by classifying the cells

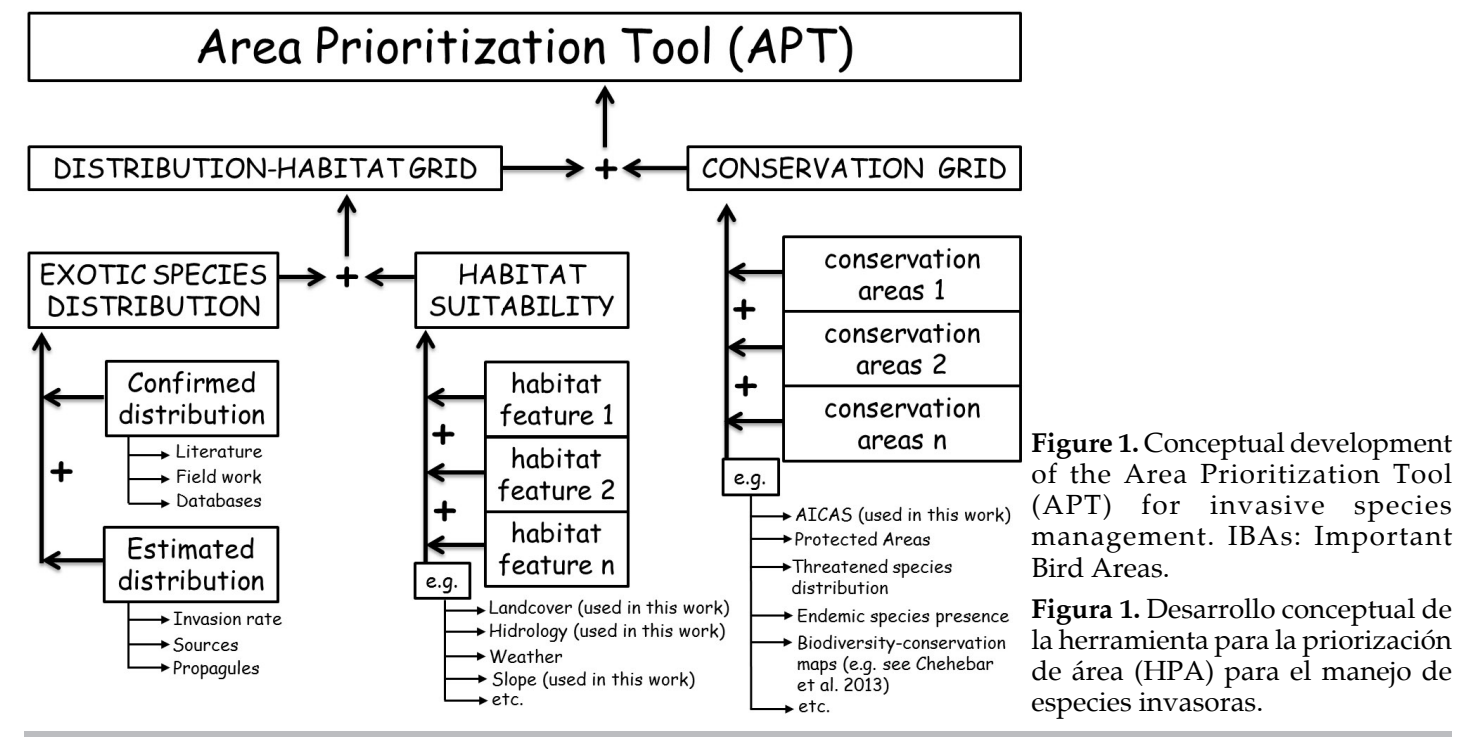


in relation to mink habitat preferences based on hydrology and vegetation and crossing this first product with information regarding mink presence (confirmed and potential) across the region (see Appendix IA for details of the construction and rationale of the process). The conservation map was based on Important Bird Areas information in relation to the presence of endangered and/or endemic bird species. This was used to give each cell a value reflecting its conservation importance (see Appendix IA for details). The final product, the APT is the result of multiplying the values for the habitat suitability-distribution map with the conservation map values. This resulted in an output grid with cells containing values of $0,1,2,3$, 4,6 and 9 (Figure 2) that were grouped into priority levels: High, Medium, Low and None.

\section{Protocol for mink Eradication Tasks (PET)}

Three high priority areas from the APT were selected for this PET (Figure 3): Lanín National Park (Lanín-Neuquén Province), Buenos Aires Lake Plateau (Buenos Aires Plateau -Santa Cruz Province) and Beagle Channel coast (Beagle Channel -Tierra del Fuego Province). Other reasons why these three areas were chosen for this exercise are: (1) the current northern limit of American mink distribution in Patagonia is within the Lanín (Fasola et al. 2011); (2) the survival of the globally endangered Hooded Grebe with only 800-900 remaining individuals depends largely on the fate of the reproductive colonies in the ponds found on the Buenos Aires Plateau (Roesler et al. 2012a); and (3) the Beagle Channel is the only place within Argentinean Patagonia where mink

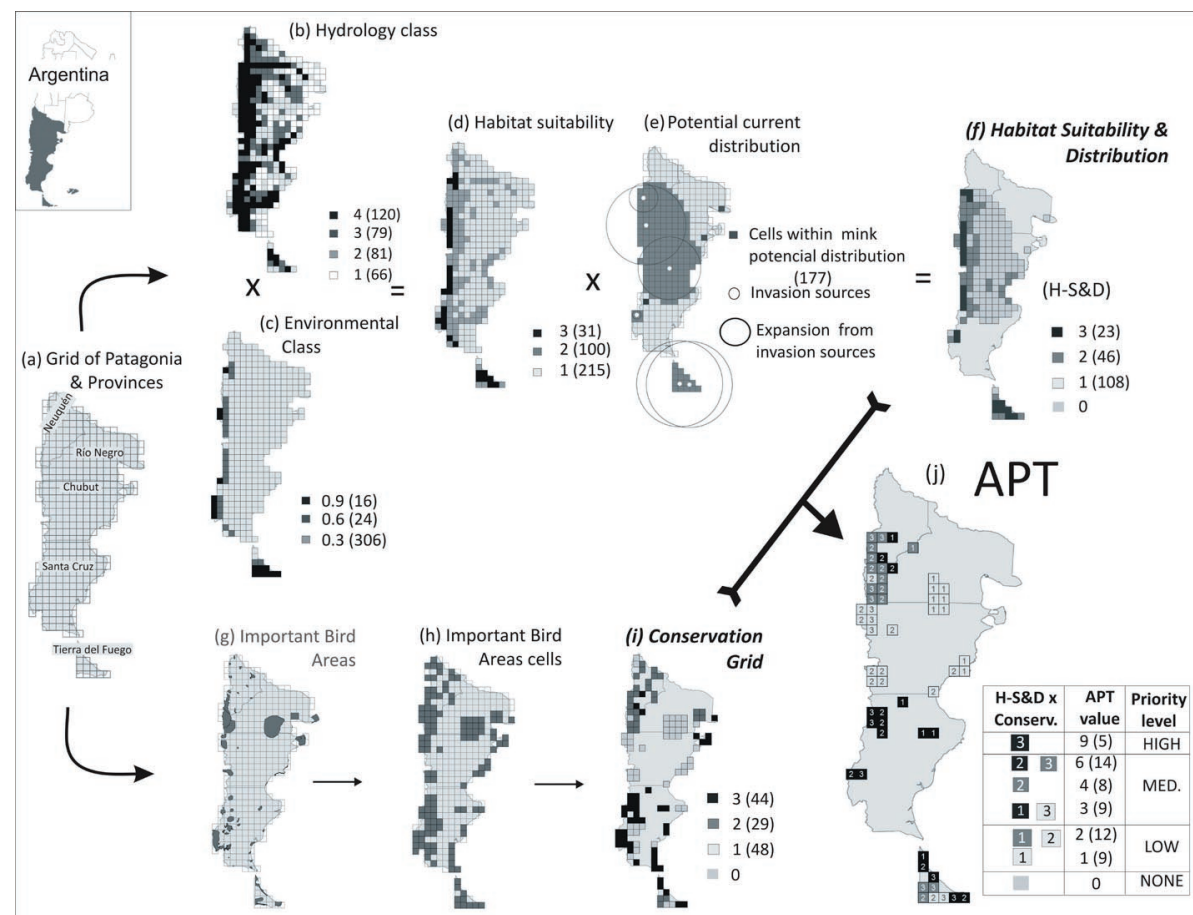

Figure 2. Area Prioritization Tool (APT) applied to American mink in Patagonia. Numbers between brackets indicate number of cells. (a) Grid over Patagonia (cells $50 \mathrm{~km}$ x $50 \mathrm{~km}$ ) and Argentinean provinces involved. (b) Hydrology classes: $1(0-247 \mathrm{~km}) ; 2(248-394 \mathrm{~km}) ; 3(395-561 \mathrm{~km})$ and $4(562-1,200 \mathrm{~km})$ of shoreline. (c) Environmental classes: forest (3- value 0.9 ), eco-tone (2-value 0.6) and steppe (1-value 0.3). (d) Habitat quality classes: $3-1.9$ to $3.6 ; 2-1.2$ to 1.8 and 1- 0.3 to 0.9. (e) Potential present distribution: cells in dark grey indicate mink presence (value 1). Other cells were valued 0. (f) Habitat Quality and Distribution (H-Q\&D): product of (d) and (e). (g) Important Bird Areas identified for Patagonia (Di Giacomo et al. 2007). (h) Cells overlapping with the Important Bird Areas. (i) Conservation value. (j) APT combination of (d) and (i); High priority level: 12,500 km²-Medium priority level: 77,500 km²-Low priority level: $52,500 \mathrm{~km}^{2}$.

Figura 2. Herramienta para la priorización de áreas (HPA) aplicada al visón Americano en Patagonia. Los números entre paréntesis indican el número de celdas. (a) grilla sobre el área de Patagonia (cada celda $50 \mathrm{~km} \times \mathrm{km}$ ) y las provincias Argentinas incluidas. (b) Clases hidrológicas: $1(0-247 \mathrm{~km}) ; 2(248-394 \mathrm{~km})$; $3(395-561 \mathrm{~km})$ y $4(562-1200$ $\mathrm{km}$ ) de costa. (c) Clases de ambiente: bosque (3-valor 0.9); ecotono (2-valor 0.6) y estepa (1-valor 0.3). (d) Clases de Calidad de Ambiente: 3-1.9 a 3.6; 2-1.2 a 1.8 y 1-0.3 a 0.9. (e) Distribución actual potencial: celdas gris oscuro indican presencia (real o potencial) de visón americano y las blancas su ausencia, con valores uno y cero respectivamente. (f) Calidad de Hábitat y distribución (H-Q\&D). (g) Área Importante para la Conservación de Aves identificadas en Patagonia (Di Giacomo et al. 2007). (h) Celdas superpuestas con Área Importante para la Conservación de Aves. (i) Valor de Conservación. (j) APT: combinación de (d) e (i); Prioridad ALTA: 12.500 km²-Prioridad Intermedia: 77.500 $\mathrm{km}^{2}$-Prioridad menor: $52.500 \mathrm{~km}^{2}$. 


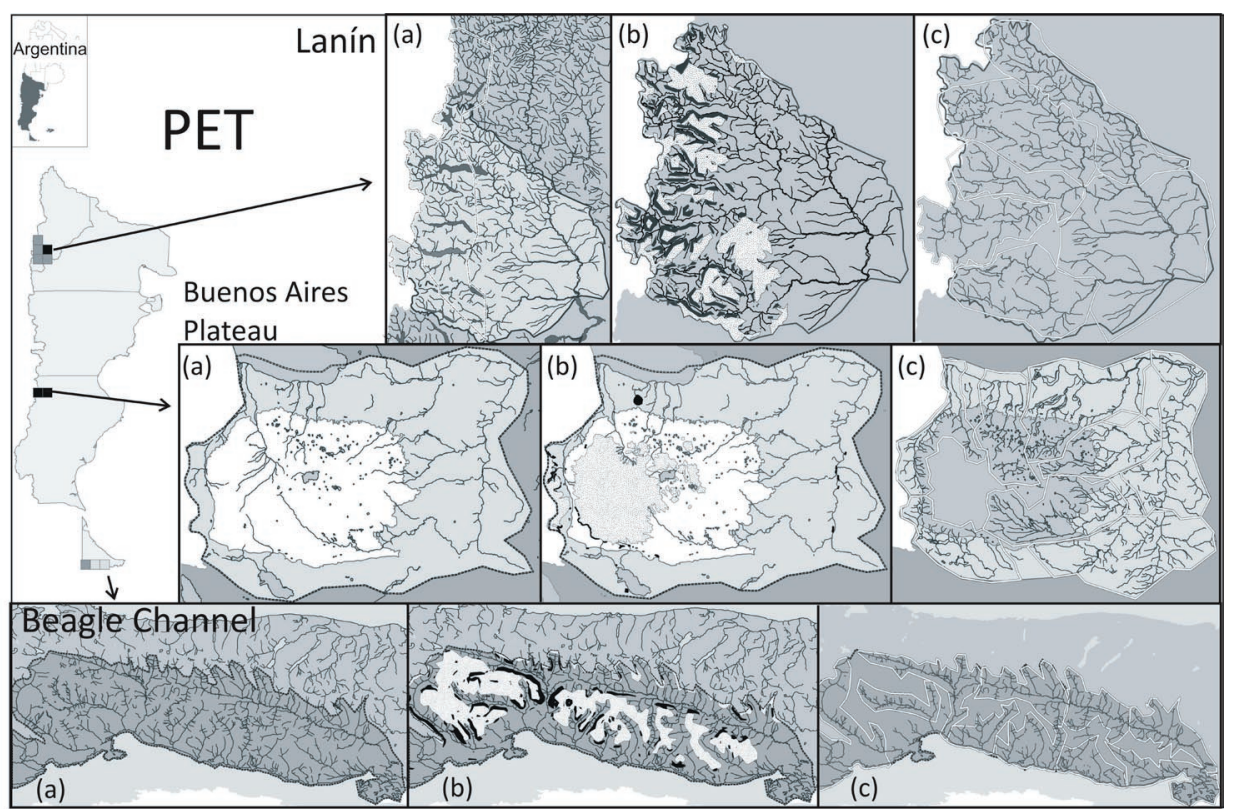

Figure 3. Protocol for Eradication Tasks (PET) at Lanín (Lanín National Park); Buenos Aires Plateau (Buenos Aires Lake Plateau), Beagle Channel: (a) total area for PET (Lanín: area-light grey, national park border-white dotted line-; Buenos Aires Plateau: area -light grey, plateau area-white-; Beagle Channel: area: -dark grey. (b) Dotted area: area over the vegetation line for Beagle Channel and Lanín, and over 1,400 m.a.s.l. for Buenos Aires Plateau. Area steeper than $25^{\circ}$ in black. (c) Work units (WU): delimited by a white thin line.

Figura 3. Protocolo de Actividades para la Erradicación (PTE). Lanín (Parque Nacional Lanín); Buenos Aires Plateau (Meseta del Lago Buenos Aires); Beagle Channel (Canal Beagle): (a) Área total para la aplicación del PTE (Lanín: área total-gris claro, límite del Parque Nacional-línea punteada blanca-; Buenos Aires Plateau: área total-gris oscuro-1-gris claro-, área de la meseta -blanco-; Beagle Channel: área total-gris oscuro-. (b) Área punteada: sector por encima de la línea de vegetación para Beagle Channel y Lanín, y sobre $1.400 \mathrm{msnm}$ para Buenos Aires Plateau. Áreas con pendiente mayor a $25^{\circ}$ en negro. (c) Unidades de trabajo: delimitadas con una línea delgada blanca.

reaches the marine coast (where abundant water fowl reproduce, such as the Flightless Steamer Duck (Tachyeres pteneres) and the Kelp Goose (Chloephaga hybrida) (Carboneras 1992). Additionally, mink control was identified as an important issue for these waterfowl's conservation (Liljesthröm et al. 2013). Moreover, these three areas are part of previous and current research fieldwork for the authors.

The development of the PET involved the definition of the total surface area where the protocol would be implemented, estimation of the removal effort using ecological information available and consideration of the climatic conditions of the area to schedule the tasks. Finally, we estimated the manpower required and the length of the period for when the protocol will be conducted to assess the funds needed to proceed with it. Total costs were estimated using 'salary' as a unit that can be interpreted relatively among areas and transformed into monetary units easily. The nature, ecology and behavior of the target species as well as the terrain characteristics defined much of the PET steps. In Appendix IB the decisions and rationale applied to our case of study, American mink in Patagonia, are developed in detail.
Digital hydrology and topography layers (scale 1: $250,000)$ used in this work were downloaded from the Argentinean National Geographic Institute (www.ign.gov.ar/sig250), and Important Bird Areas layers were provided by the conservation NGO Aves Argentinas-Asociación Ornitológica del Plata.

\section{RESULTS}

\section{Area Prioritization Tool (APT)}

Within the total area of Argentinean Patagonia 3(46 cells,Figure 2a) we considered six invasion sources located in Neuquén (1), Chubut (2), Santa Cruz (1) and Tierra del Fuego (2) Provinces (Figure 2.a). Survey records, isolated records (Jones 2011; M. Martínez and D. Barreto pers. comm.; Figure 2e) and expansion estimation from sources of invasions defined a current potential mink presence in 177 cells with the addition of three cells (51.1\% of all cells). The classification of cells based on hydrology (Figure 2b) and habitat type (Figure 2c) resulted in the habitat suitability map (Figure 2d) with 215, 100 and 
Table 1. Estimation of effort and relative costs associated with eradication tasks at Lanín; Buenos Aires Plateau and Beagle Channel. ${ }^{1} 41$ trap-days $/ \mathrm{km}$ *shoreline total length $(\mathrm{km})$ (Zabala et al. 2010). ${ }^{2}$ Number of traps needed for 41 days of effective trapping at every $1 \mathrm{~km}$ of shoreline = work unit $(\mathrm{WU})$ shoreline length $/ 2$ (considering a rotation of traps at each unit). ${ }^{3}$ Number of traps needed at each WU/ 20 (number of traps operated per person per day). ${ }^{4}$ Trappers per WU * 5 (months of work). ${ }^{5}$ Salaries for trappers for all the WU. ${ }^{6}$ Montoring $1-\mathrm{km}$ transect every $5 \mathrm{~km}$ of shoreline: (shoreline length $/ 5$ ). ${ }^{7}$ Salaries needed for monitoring per WU (range) $=$ total transects $* 2$ (double survey) $/ 4$ (transects covered by a surveying team per day) $/ 30$ (days in a month)*2 (a surveying team). The minimum number of salaries considered per WU was $1 .{ }^{8}$ Staff movement costs during management activities (trapping and monitoring) $=30 \%$ of the total budget for staff salaries. ${ }^{9}$ Measured as the total of monthly salaries needed.

Tabla 1. Estimación del esfuerzo y costos relativos asociados a las tareas de erradicación. Ver detalles en la leyenda en inglés.

\begin{tabular}{lccc}
\hline & Lanín & BAPlateau & Beagle Channel \\
\hline Habitat & Forest-Ecotone & Steppe & Forest \\
Area $\left(\mathrm{km}^{2}\right)$ & 9,132 & 4,901 & 1,322 \\
Shoreline length $(\mathrm{km})$ & 2,917 & 1,622 & 1,061 \\
Work units $(\mathrm{N})$ & 6 & 7 & 10 \\
Work unit area (range km) & $662-1,889$ & $377-954$ & $58-172$ \\
Shoreline length per work unit (range km) & $220-720$ & $117-305$ & $63-161$ \\
${ }^{1}$ Trapping effort (range) & $9,026-29,518$ & $4,797-12,505$ & $2,602-6,594$ \\
${ }^{2}$ Number of traps (range | total) & $111-360 \mid 1,458$ & $59-153 \mid 811$ & $32-80 \mid 530$ \\
${ }^{3}$ Trap operators per work unit (min.-max.) & $5-17$ & $4-7$ & $2-4$ \\
${ }^{4}$ Number of monthly salaries for trappers per work unit (range) & $25-85$ & $20-356$ & $10-20$ \\
${ }^{5}$ Total monthly salaries for trappers & 350 & 180 & 110 \\
${ }^{6}$ Postmanagement monitoring transects (range | total) & $45-144 \mid 587$ & $24-61 \mid 328$ & $13-33 \mid 217$ \\
${ }^{7}$ Number of monthly salaries for per work unit for monitoring (range) & $2-5$ & $1-2$ & 1 \\
Total monthly salaries for monitoring & 22 & 12 & 10 \\
Total salaries & 372 & 192 & 120 \\
${ }^{8}$ Fuel costs (in salaries) & 111 & 57.6 & 36 \\
9Total Costs (in salaries) & 483 & 249.6 & 156 \\
\hline
\end{tabular}

31 cells for Classes 1, 2 and 3, respectively. After combining habitat suitability and the potential-current distribution maps, we obtained the habitat suitability-distribution map (Figure 2f) with 108, 46 and 23 cells for habitat quality Classes 1,2 and 3, respectively and 169 cells where mink is not present.

There are 55 Important Bird Areas in Patagonia (Figure 2g) that overlapped 121 cells (Figure $2 \mathrm{~h}$ ). The reclassification of these cells based on the bird areas index proposed in this work resulted in the conservation grid map with 48, 29 and 44 cells for the 1, 2 and 3 Important Bird Areas classes, respectively (Figure 2i). The APT (Figure 2j) showed a total of $18\left(45,000 \mathrm{~km}^{2}\right), 15\left(37,500 \mathrm{~km}^{2}\right)$ and 24 $\left(60,000 \mathrm{~km}^{2}\right)$ cells for descending conservation values of 3,2, and 1 with American mink presence. According to the APT output, there were 5 cells within the high, 13 cells in the medium and 21 in the low priority levels.

We found that all the high priority cells were concentrated in southern Patagonia: 3 cells in Santa Cruz and 2 in Tierra del Fuego. Almost all cells within these provinces were high or medium priority levels. Cells exclusively from
Chubut were all of the lowest priority level (13), while in Neuquén Province, almost all cells (11 out of 13) were of medium priority. Half (6) of the cells within Río Negro were of medium priority level, and the rest were assigned to the lowest priority level. APT results indicated that Buenos Aires Plateau constitutes a top priority area, which coincides with the concern previously expressed by managers and scientists about the fate of the Hooded Grebe (Roesler et al. 2012a,b). Similarly, Tierra del Fuego Province is an important region for the reproduction, feeding and migration of several bird species (Di Giacomo et al. 2007), and was almost completely included within the medium and high prioritization categories.

\section{Protocol to Eradication Tasks (PET)}

The largest selected priority area corresponded to Lanín with $9,132 \mathrm{~km}^{2}$, encompassing six work units (Table 1; Figure 3 LNP) followed in size by Buenos Aires Plateau with $4,901 \mathrm{~km}^{2}$ and seven work units (Table 1; Figure 3 BALP). Finally, Beagle Channel represented the smallest area $(1,322$ $\mathrm{km}^{2}$ ) with several sub-catchments reaching the marine coast that defined ten different 
and independent work units (Table 1; Figure 3 Beagle Channel). The details associated to PET calculations for these areas are presented in Table 1.

The areas of Buenos Aires Plateau and Beagle Channel were $53 \%$ and $14 \%$ of the area of Lanín, respectively. Total shoreline length in each area was 2,917 km for Lanín, 1,622 km for Buenos Aires Plateau and 1,061 km for Beagle Channel. Consequently, the PET cost estimations for Buenos Aires Plateau and Beagle Channel were approximately half (51\%) and a third (32\%) of the estimated cost to eradicate mink from Lanín (483 total salaries, see Table 1 ).

\section{Discussion}

\section{The Tool}

This work focuses on resolving dilemmas common to managers and conservation biologist when facing situations that involve invasive species and limited knowledge of the species population biology and behavior in the novel environment. We present here a tool for the management of a carnivore species introduced to a region, following a conceptual structure that could be adapted to other scenarios and/or species. In this case, the invasive species (American mink) has spread in the region (Patagonia) to an extent that eradication is no longer feasible (Fasola et al. 2011) at the regional level; therefore, the need of a prioritization of areas emerges where management actions need to be applied, attending specific situations.

Here, our tool prioritizes areas in Patagonia by combining a habitat suitability map, based on basic ecological knowledge and a distribution map of American mink with areas of importance for biodiversity conservation. This APT offers a potentially effective, quick, useful and simple tool for managers to identify priority areas for exotic species management and native ecosystems conservation. We go beyond this scientific-based APT and lay out a detailed estimate of the effort required in terms of time and economic cost to implement the eradication of mink from selected areas using a design and methodologies from successful eradication experiences developed elsewhere (Moore et al. 2003; Zabala et al. 2010; Bryce et al. 2011; Roy 2011).

The APT involved using in a conceptual rationale the existing knowledge of the species in the region. Even when extrapolation of information does not lead to an accurate habitat model, we chose to apply a habitat use model developed for a reduced area (Tierra del Fuego, Valenzuela et al. 2013b) as an indicative measure for the region. An adaptive approach for future work incorporating new information will improve this initial approach (this also applies to the PET as information from studies elsewhere were used to take decisions in the design of the eradication plan). Finally, the procedure only required basic knowledge of Geographical Information Systems to make an operational use of the ecological niche to predict mink presence/abundance. We are aware that more sophisticated approaches to build habitat suitability models can lead to more accurate information about potential distribution of species in the absence of this information. Depending on the nature of data available, GLMs or GAMs can be applied to presence-absence data or GARP, ENFA or MaxEnt with presence only information (Hirzel \& Le Lay 2008, Elith et al. 2011). Therefore, the use of any of these approaches would be preferred if personnel with expertise in such procedures can develop an improved habitat model for the species and the area under study.

It is important to consider at this point other type of information emerging from the application of this tool to our study case, the American mink. In our example, areas within the potential mink distribution but outside the confirmed mink range are suggested to be evaluated for mink presence (surveyed) as a first action, and this can follow the priority order obtained by the APT. Additionally, we suggestimplementing an "early alert program" for these areas combining the implementation of a system to recover reliable information from different stakeholders (e.g., rangers, landowners, fishermen, etc.) supported by an adequate dissemination of information about the species including tips for its detection. Also important for the case presented here is to note that using exclusively Important Bird Areas information lead us to a partial APT, as this ignores the conservation needs of other group of vertebrates. Including information of these other groups would result in a more comprehensive APT for Patagonian region in relation to American mink impact.

The second step is to design management strategies (PET) for the priority areas (cells) where mink presence is confirmed. A tradeoff 
between the conservation issues related to the species or ecosystem we want to protect and the real chances of achieving success in eradicating the invasive species should be evaluated specifically at each area. For the American mink, experiences elsewhere have shown that management success can be achieved at several spatial scales and using different approaches. A small scale mink control programs, such as the water vole (Arvicola terrestris) restoration and mink removal effort in southern England, where this mustelid was removed from river sections of about $20 \mathrm{~km}$ each for three years, was successful to secure the recovery of the native prey (Harrington et al. 2009). These authors sought to lower the number of mink to a level adequate to promote the persistence of the reintroduced water vole population. Following a similar approach, Nordström et al. (2003) removed American mink from certain islands in the Baltic Sea to increase breeding densities of birds and Zabala et al. (2010) demonstrated that after eradication from continental small catchments (ca. $180 \mathrm{~km}^{2}$ ) the removed population could be considered as closed to immigration in the short term.

At a broader scale, experiences for mainland areas, as well as for large archipelagos, also demonstrated that an adequate planning with constant and adaptive management work could lead to a successful mink eradication program. For example, Roy (2011) described the outcomes of the first phase (5 years) on the eradication of mink from an archipelago $\left(1,100 \mathrm{~km}^{2}\right)$ where $c a .540$ mink were removed with full time staff in charge of trapping and culling the animals. On the other hand, Bryce et al. (2011) show the results of the most extensive mink eradication program to date in which mink were removed from a ca.10,570 $\mathrm{km}^{2}$ area after 3 years of constant effort, involving several stakeholders (researchers, landowners, volunteers and project employees). In synthesis, several approaches have been tested and proven to have favorable outcomes, depending on the area to be managed and the objectives that are pursued in mink management. So, a first step in choosing an adequate approach to each area in Patagonia is to frame the situation based on known and described experiences. Then, a careful identification of deviations from the original case should follow as a way to contextualize to the local situation under consideration.
The three examples of PET presented may involve several years of intense work during the favorable months in Patagonia. However, it is possible to complete the protocol in all work units in a single season if resources (traps, staff and funds) are available simultaneously. Also, the extension of the areas of management includes jurisdiction of different national and provincial government offices. Therefore depending on the area, the PET may require a multi-disciplinary approach and cooperative work in order to secure the continuation of the management tasks until completion (Skurka Darin et al. 2011). For instance, the three areas presented in this work include sections of national parks, provincial lands and also private lands, which indicates that the PET need to be planned by a consortium involving the provincial government's environmental office, Argentinean National Parks Administration and other stakeholders

\section{Conclusion}

In this work, we propose a tool (and a rationale) that could allow managers to rapidly prioritize areas to manage exotic species, particularly carnivores. This APT should prompt a more effective decisionmaking process by allocating limited resources to manage problematic invasive carnivores in the areas with the greatest conservation priority. This tool may be applied as we described it or adapt the criteria definitions and scoring according to the conservation needs of a particular case and the target exotic species (e.g., use different habitat layers, spatial distances, conservations maps or criteria, etc.).

Additionally, with the PET, we sought to assist managers to address a situation related to an invasive species in terms of (a) defining work units that will allow an organized application of the protocol, (b) estimating the effort needed to conduct the tasks associated with eradication and (c) evaluating the time required to complete the plan to achieve the management goal. This will allow an approximate initial estimation of the costs that are needed to fulfill the PET, which is itself the first step for budget organization and fundraising process. The protocol should be planned as an initial working scheme, which needs to be flexible enough to incorporate new information gathered during the process. By doing this, the protocol will work under an adaptive scheme. This means that actions 
can start even when information is not very accurate to the particular case and the area, but that adjustments during the implementation will lead to the right contextualization needed to reach the objectives proposed for the area under management.

Far from considering these protocols as definite, they are a way to go forward in confronting the invasive species problem.

AcKnowledgements: This work is a product of the symposium Invasive Species in Patagonia, organized by the authors at the $25^{\text {th }}$ Argentinean Ecological Association Meeting with the support of the Omora Sub-Antarctic Research Alliance. We thank I Roesler for guidance on IBA bibliography, providing information on endangered species and making constructive and very helpful comments on a previous version of the manuscript. C Anderson edited previous versions of the manuscript, reviewed the English and provided comments. Aves Argentinas-Asociación Ornitológica del Plata provided layers on IBAs. We thank the two anonymous reviewers for their valuable comments that considerably improved our manuscript.

\section{REFERENCES}

Bryce, R; MK Oliver; L Davies; H Gray; J Uruquhart \& X LAMBIN. 2011. Turning back the tide of American mink invasion at an unprecedented scale through community participation and adaptive management. Biol. Conserv., 144:575-583.

Burkart, R; NO BÁRbARO; RO SANCHEZ \& DA GÓMEZ. 1999. Ecoregiones de la Argentina. Secretaría de Ambiente y Desarrollo Sustentable. Pp 43.

Cabrera, AL. 1971. Fitogeografía de la República Argentina. Boletín de la Sociedad Argentina de Botánica, 14:1-42.

Carboneras, C. 1992. Family Anatidae (ducks, geese and swans). Pp: 528-628 in: del Hoyo, J; A Elliot \& J Sargatal (eds.). Handbook of birds of the world. Vol1. Lynx Editions.

CrawFord, A. 2010. Fifth otter survey of England 2009-2010. Technical report. Environment Agency, Bristol.

Di Giacomo, AS; MV De Francesco \& EG Coconier (eds.). 2007. Áreas Importantes para la Conservación de las aves en Argentina. Sitios prioritarios para la conservació de la biodiversidad. Temas de Naturaleza y Conservación 5. Edición Revisada. Aves Argentinas/Asociación Ornitológica del Plata, Buenos Aires.

ELITH J; SJ Phillips; T Hastie; M Dudík; YE Chee \& CJ Yates. 2011. A statistical explanation of MaxEnt for ecologists. Diversity Distrib., 17:43-57.

Fasola, L; J Muzio; C Chehébar, M Cassini \& DW Macdonald. 2011. Range expansion and prey use of American mink in Argentinean Patagonia: dilemmas for conservation. Eur. J.Wildl. Res., 57:283-294.

FOERSTER R. 1973. Estudio integral sobre la presencia de visones (Mustela vison) en el Parque Nacional los Alerces y zona de in uencia. Technical report, Centro de Documentación, Administración de Parques Nacionales, Argentina.

García-MAta, R. 1982. El visón. Su cría en cautividad. Editorial Hemisferio Sur S.A., Buenos Aires, Argentina.

Godoy, J. 1963. Fauna Silvestre. Vol I, II, VII. Technical
Report. Consejo Federal de Inversiones, Buenos Aires, Argentina.

Harrington, LA; AL Harrington; T Moorhouse; M Gelling; L Bonesi \& DW Macdonald. 2009. American mink control on inland rivers in southern England: An experimental test of a model strategy. Biol. Conserv., 142:839-849.

Harrington, LA \& DW Macdonald. 2008. Spatial and temporal relationships between invasive American mink and native European polecats in the southern united kingdom. J. Mammal., 89:991-1000.

HIRZEL, AH \& G LE LAy. 2008. Habitat suitability modeling and niche theory. J. App. Ecol., 45: 1372-1381.

IORDAN, F; SP Rushton; DW MACDONALd \& L Bonesi. 2012. Predicting the spread of feral populations of the American mink in Italy: is it too late for eradication? Biol. Invasions, 14:1895-1908.

JAKSIC, FM; J Agust; JE JIM \& DR MART. 2002. Invaders without frontiers: cross-border invasions of exotic mammals. Biol. Invasions, 4:157-173.

JAKSIC, FM \& JL YANEZ. 1983. Rabbit and fox introductions in Tierra del Fuego: history and assessment of the attempts at biological control of the rabbit infestation. Biol. Conserv., 26:367-374.

JONES, AC. 2011. Distribución del visón (Mustela vison) en la provincia del Chubut y posibles con ictos con actividades humanas. Undergraduate Thesis, National University of Patagonia.

LIJjESTHRÖM, M; A SCHIAVINI; RA SÁENZ SAMANIEGO; L FASOlA \& A Raya Rey. 2013. Kelp Geese (Chloephaga hybrida) and the Flightless Steamer Ducks (Tachyeres pteneres) in the Beagle Channel: the importance of islands in providing safe nesting habitat. Wilson J. Ornith., 125:583-591.

LOWE, S.; M Browne; S BOUdJElas \& M De POORTER. 2000. 100 of the World's Worst Invasive Alien Species a Selection from the Global Invasive Species Database. The Invasive Species Specialist Group (ISSG) a specialist group of the Species Survival Commission (SSC) of the World Conservation Union (IUCN). Updated and reprinted ver sion: November 2004. Aliens: Invasive Species Bull. 12

Macdonald, DW \& R Stratchan. 1999. The mink and the watervole. Analyses for Conservation. Wildlife Conservation Research Unit \& Environmental Agency, Oxford, United Kingdom. 161pp.

Macdonald, DW; VE Sidorovich; T Maran \& H KruUK. 2002. European Mink. Mustela lutreola. Analyses for conservation. WildCRU and Darwin Initiative, Oxford, United Kingdom. 122pp.

Macdonald, DW \& LA Harrington. 2003. The American mink: the triumph and tragedy of adaptation out of context. N. Z. J. Zool., 30:421-441.

Mack, RN; D Simberloff; WM Lonsdale ; H Evans; M Clout \&FA Bazzaz .2000. Biotic invasions: causes, epidemiology, global consequences and control. Ecological Applications, 10: 689-710.

Maley, BM; CB Anderson; K Stodola \& AD Rosemond. 2011. Identifying native and exotic predators of groundnesting songbirds in sub-Antarctic forests of southern Chile. Anales del Instituto de la Patagonia, 39:51-57.

MAZAR BARNETT, J; S IMBERTI \& I ROESLER. 2013. Distribution and habitat use of the Austral Rail (Rallus antarcticus) and perspectives on its conservation. Bird Conserv, 24: 114-125.

Moore, NP; SS Roy \& A Helyar. 2003. Mink (Mustela vison) eradication to protect ground-nesting birds in 
the Western Isles, Scotland, United Kingdom. N. Z. J. Zool., 30:443-452

Nordstrom, M; J Hogmander; J Laine; J Nummelin; N LAANETU \& E KoRPIMÄKI. 2003. Effects of feral mink removal on seabirds, waders and passerines on small islands in the Baltic Sea. Biol. Conserv., 109:359-368.

NuÑEZ, MA \& A PAUCHARD. 2010. Biological Invasions in developing and developed countries: does one model fit all? Biol. Invasions, 12:707-714.

PAGNONI, G; J GaRRIDO \& M Marin . 1986. Impacto económico y ambiental del visón. Mustela vison (Schreber 1877) en el norte de la Patagonia. Technical report, CENPATCONICET, Dirección de Fauna de la Provincia de Chubut. 20pp.

Peris, SJ; J Sanguinetti \& M Pescador. 2009. Have Patagonian waterfowl been affected by the introduction of the American mink Mustela vison? Oryx, 43:648-654.

Petracci, P; R Sarria; F Gaitán \& L Fasola. 2013. Estatus poblacional de los cauquenes (Chloephaga $s p$.) en las áreas reproductivas del extremo sur de la Patagonia Argentina. Technical report, Dirección de Fauna Silvestre, Secretaría de Ambiente y Desarrollo Sustentable de la Nación, Buenos Aires.

Roesler, I; S IMberti; H CASAÑAs; B MAhLer \& JC Reboreda. 2012a. Hooded Grebe Podiceps gallardoi population decreased by eighty per cent in the last twenty-five years. Bird Conserv. Int., 22:371-382.

Roesler, I; S Imberti; H Casañas \& N Volpe. 2012b. A New Threat for the globally endangered Hooded Grebe Podiceps gallardoi: the American mink Neovison vison. Bird Conserv. Int. 22(04):383-388.

RoY, S. 2011. Strategies to improve landscape scale management of mink populations in the west coast of Scotland: lessons learned from the uists 2001-2006. Pp. 114-117 in: Veitch, CR; MN Clout \& DR Towns (eds.). Island invasives: eradication and management. IUCN, Gland.
SAATY, A. 2008. Decision making with the analytic hierarchy process. Int. J. Serv. Sci., 1:83-98.

Sanguinetti, J; L Buria; L Malmierca; C Nuñez; AEJ Valenzuela et al. 2014. Ciencia y gestión para el manejo de especies exóticas en Argentina: necesidades de integración desde la Administración de Parques Nacionales. Ecol. Austral, This Special Section.

SIMBERLOFF, D. 2003. How much information on population biology is needed to manage introduced species? Conserv. Biol., 17:83-91.

SKurKa Darin, GM; S Schoenig; JN Barney; FD PanetTa \& JM DiTomaso. 2011. WHIPPET: A novel tool for prioritizing invasive plant populations for regional eradication. J. Environm. Manag., 92:131-139.

VALENZUELA, AEJ; A RAYa Rey; L Fasola; RA SÁEnz SAMANIEGo \& A SCHIAVINI. 2013a. Trophic ecology of a top predator colonizing the southern extreme of South America: Feeding habits of invasive American mink (Neovison vison) in Tierra del Fuego. Mammal. Biol., 78:104-110.

Valenzuela, AEJ; A Raya Rey; L Fasola \& A Schiavini. 2013b. Understanding the inter-specific dynamics of two co-existing predators in the Tierra del Fuego Archipelago: the native southern river otter and the exotic American mink. Biol. Invasions, 15:645-656.

Valenzuela, AEJ; CB Anderson; L Fasola \& JL Cabello. 2014. Linking invasive exotic vertebrates and their ecosystem impacts in Tierra del Fuego to test theory and determine action. Acta Oecol., 54:110-118.

VitouseK, PM; HA MoOney; J Lubchenco \& JM Melillo. 1997. Human domination of Earth's ecosystems. Science, 277:494-499.

Zabala, J.; I Zuberogoitia \& JA GonZÁlez-Oreja. 2010. "Estimating costs and outcomes of invasive American mink (Neovison vison) management in continental areas: a framework for evidence based control and eradication. Biol. Invasions, 12:2999-3012. 


\section{SUPPLEMENTARY INFORMATION}

\section{APPENDIX IA}

\section{Habitat suitability-distribution map}

The habitat suitability map combined layers of hydrology and habitat preference, reflecting basic information about mink ecology in the region. As the mink is a semiaquatic mammal, we calculated the combined length of the shoreline of permanent waterways (rivers, streams, lake and lagoons) in each cell and defined four hydrological classes $(1$, $2,3$ and 4$)$ by quartiles from low $(<1 \mathrm{~km})$ to high $(\sim 1,200 \mathrm{~km})$. Each cell was then assigned to the one of the following ecoregion types: forest, steppe or ecotone, depending on which of these habitats occupied more than the $50 \%$ of the cell, and a landcover map was built. Based on similarities in terms of aridity between the monte and the steppe, these ecosystems were grouped into steppe.Decreasing weight values were defined for forest, ecotone and steppe $(0.9,0.6,0.3$, respectively) based on the relative probability of presence of mink, modeled from Valenzuela et al. (2013)for different landscapes of Tierra del Fuego that share structural characteristics with the mainland Patagonian environments. Then, we combined both maps by multiplying the hydrology value with the landcover weight value of each cell, obtaining a range of cell values from 0.3 to 3.6. Finally, the map was reclassified into three classes $(1: 0.3$ to $0.9 ; 2: 1.2$ to $1.8 ; 3: 1.9$ to 3.6 ) where class 3 indicates the cells with highest and class 1 those with the lowest values for mink presence.

The map of the mink's potential current distribution in the region has two components. First, we considered all the published locations were mink are confirmed (Fasola et al. 2011; Valenzuela 2011, Mazar Barnett et al. 2013), positive locations recorded by the authors in occasional surveys in the region and also reported to the authors (G. Aprile pers. comm., M. Martínez pers. comm., A. Jones pers. comm., D. Barreto pers. comm.), totaling 216 gathered since 2002. The second component is based on an estimation of colonization distance from known mink introduction sources: points where mink were released (e.g., fur farms: Pagnoni et al. 1986; Jaksic et al. 2002) and sites invaded from Chile (Peris et al. 2009; Mazar Barnett et al. 2013; G. Aprile pers. comm.). Then, we got a buffer area around source points by multiplying an estimated expansion rate in Patagonia (7.3 $\mathrm{km}$ /year; Fasola et al. 2011) by the years since release or invasion detection. Finally, we overlapped mink presence points with the grid of Patagonia to get a mink distribution map in the region, where cells with mink potential/current presence were valued as 1 and the absence cells were 0 .

To get the distribution habitat grid we multiplied the values from both maps (habitat suitability map and distribution map). Value or class 3 includes cells potentially occupied by mink with optimal habitat, while 2 and 1 indicate decreasing habitat quality. Zero values indicate cells outside the mink's range.

\section{Conservation map}

We gave each IBA a conservation value by adding the number of Patagonian endemic species to the number of nationally and international endangered species present (Di Giacomo 2007). We classified these values (range: 0 to 32, median: 14) into 3 groups: 1) from 0 to 14 spp., 2) 15 to 23 spp., and 3) 24 to $32 \mathrm{spp}$. IBAs with presence of the globally critically endangered Hooded Grebe (Podiceps gallardoi) (Roesler et al. 2012a, IUCN 2013), the nationally endangered Austral Rail (Rallus antarticus) and the nationally critically endangered Ruddy-headed Goose (López Lanúset al. - AA/AOP \&SAyDS 2008) were assigned automatically the value of 3 . Each grid cell overlapping a portion of an IBA area was given the corresponding value of the conservation value of the relevant IBA. When a cell overlapped with more than one IBA, the cell was given the highest value among the IBAs involved. An extra cell in Santa Cruz Province was given a conservation value of 3 , as it hosts a group of Austral Rails, even though it does not appear in the IBA list (Mazar Barnett et al. 2013).

Cell values in both maps were multiplied to obtain an output grid with values of 0,1 , 2, 3, 4, 6 and 9 (Figure 2). Maximum priority cells were those with an output value of 9 (conservation class 3 and habitat suitabilitydistribution class 3 ). The medium priority level involved cells with output values of 3,4 and 6 (and includes the remaining cells with conservation value of 3). Output values 2 and 1 were the least priority order. Zero indicated absence of mink within the IBA map. 


\section{APPENDIX IB}

Development of the PET consisted of the following steps:

1.-Define the total surface area where it would be implemented.

2.-Since mink become resident in areas where vegetation ensures prey availability (Iordan et al. 2012), select areas close to water systems (Harrington \& Macdonald 2008) and with shoreline slopes between $10^{\circ}$ and $28^{\circ}$ (Valenzuela et al. 2013). Also, based in our personal experience, trapping is difficult in terrain with a slope over $25^{\circ}$, and therefore, using a digital elevation model (DEM) extract portions of waterways below treeline $(1,600$ m.a.s.l. for Lanin and 600 m.a.s.l. for Beagle Channel, this does not apply for Buenos Aires Plateau) and with slopes under $25^{\circ}$.

3.-Delimit work units as independent subareas defined to achieve PET goals based on hydrology. The total area can be thought of as a complete catchment, and work units as subcatchments (ideally rivers or streams of first and second order and their associated lentic water bodies). Work units must be defined as rather "closed systems" with identifiable key points for monitoring to prevent recolonization while tasks are taking place within other units. A similar design proved to be successful in northeastern Scotland, where mink were eradicated from a continental area of $10,570 \mathrm{~km}^{2}$ (Bryce et al. 2011). Eradication within a work unit should be achieved within a season so recolonization is prevented and monitoring is feasible.

4.-Calculate the total length of the shoreline of the hydrology network per work unit to calculate trapping effort.

5.-Determine mink density per $\mathrm{km}$ of shoreline within the area to calculate trapping effort needed for eradication. Zabala et al. (2010) modeled trapping effort to eradicate mink from a continental area and suggested different models for different starting population densities or "scenarios." They defined optimistic, intermediate and pessimistic scenarios associated to mink densities of $0.68,0.94$ and 1.35 individuals $/ \mathrm{km}$ respectively. Preliminary trapping experiences resulted in density estimations of 0.37 mink / $\mathrm{km}$ in Lanin (Fasola, unpublished data) and between 0.29-0.45 mink $/ \mathrm{km}$ in Beagle Channel (Fasola unpublished data), unpublished data), which are below the optimistic scenario density proposed by Zabala et al. (2010). Since Buenos Aires Plateau is entirely in the Patagonian steppe (non-preferred habitat), we assumed that mink densities are also below 0.68 individuals $/ \mathrm{km}$. Therefore, to estimate the mink extraction effort needed in the three target areas per $\mathrm{km}$, we used an optimistic scenario, following Zabala et al. (2010): $y=x$ / $(0.203+0.005 x)$, where " $y$ " is the proportion of mink population to be extracted and " $x$ " is the effort (in trap nights) needed to such objective. To achieve eradication $(y=100)$, the effort needed is 41 trap nights per $\mathrm{km}$.

6.-Asses the appropiate working period considering mink movements and trapping efficiency peaks during mating (mid-late Winter) and kit dispersal (midlate Summer)(Yamaguchi \& Macdonald 2003; Roy 2011).Nonetheless, fieldwork in Patagonia during winter was discarded due to unsafe weather and road conditions so, mid-December to mid-May was the period selected for this PET.

7.-Calculate the manpower needed at each work unit based on the length of shoreline where trapping must be conducted and the number of traps that can be handled by a single person per day. Trappers in the Hebridean Mink Project were capable of checking 30-50 traps each day (Roy 2011), but based on the authors' fieldwork experience at each of the areas selected and the region's logistical constraints, we considered as a realistic scenario that a single trapper could check 20 traps per day.

8.-Monitoring will continue after trapping. A monitoring team must conduct exhaustive sign surveys to detect any animal that could have gone undetected during trapping, up to one year after the completion of the trapping tasks. This will involve $1 \mathrm{~km}$ of sign survey every $5 \mathrm{~km}$ of shoreline at each work unit, to assess home ranges of different animals (male mink mean home range Oxfordshire UK 3.4 $\mathrm{km}$ of river length, Harrington \& Macdonald 2008).

9.-Estimate total PET costs to allow budget planning and subsequent fundraising for its application. The number of staff required for each work unit and the total number of work units within the area will define the number 
of salaries to be paid and the years needed to achieve the objective of PET. Then, the salaries of the monitoring team for the second year at each work unit should be added. Zabala et al. (2010) suggested that fuel needed for staff mobility during fieldwork represented up to $30 \%$ of the total budget designated to salaries. In terms of equipment, the number of traps needed was estimated as the total traps required per work unit to secure one trap at every $\mathrm{km}$ operating for 41 nights, which means that traps can be shifted to new locations within the units during one season as a 'rolling front' (King et al. 2009) (see Table 1). Costs related to bait were notincluded since these depend on local availability of bait types (fish, rabbits, hares, etc.). The budget related to the humane disposal of mink must also be included. Every trapper should carry the elements to proceed with the more general methods for killing (e.g., air pistols, rifles, lethal anesthesia, etc.).

\section{REFERENCES}

Bryce, R; MK Oliver; L Davies; H Gray; J Uruguhart \& X LAMBIN. 2011. Turning back the tide of American mink invasion at an unprecedented scale through community participation and adaptive management. Biol. Conserv. 144:575-583.

Fasola, L; J Muzio; C Chehébar, M Cassini \& DW MACDONALD.2011. Range expansion and prey use of American mink in Argentinean Patagonia: dilemmas for conservation. Eur. J.Wildl. Res. 57:283-294.

Harrington, LA \& DW Macdonald. 2008. Spatial and temporal relationships between invasive American mink and native European polecats in the southern united kingdom. J. Mammal. 89:991-1000.

IORDAN, F; SP Rushton; DW MACDONALD \& L BONESI. 2012. Predicting the spread of feral populations of the
American mink in Italy: is it too late for eradication? Biol. Invasions 14:1895-1908.

IUCN 2013.IUCN Red List of Threatened Species.Version 2013.2.<www.iucnredlist.org>. Downloaded on 02 January 2014.

KInG, CM; RM McDonald; RD Martin \& T Dennis. 2009. Why is eradication of invasive mustelids so difficult? Biol. Conerv., 142: 806-816.

López-Lanús, B; P Grilli; E Coconier; A Di Giacomo \& R BANChs. 2008. Categorización de las aves de la Argentina según su estado de conservación. Technical Report, Aves Argentinas / AOP \& Secretaría de Ambiente y Desarrollo Sustentable. Buenos Aires, Argentina.

MaZarBarnett, J; S IMberti \& I RoesLer. 2013. Distribution and habitat use of the Austral Rail (Rallus antarcticus) and perspectives on its conservation. Bird Conserv. Int. DOI:http:/ /dx.doi.org/10.1017/S0959270913000257.

Roesler, I; S IMBerti; H CASAÑas; B MAHLER \& IC REBoreda. 2012. Hooded Grebe Podiceps gallardoi population decreased by eighty per cent in the last twenty-five years. Bird Conserv. Int., 22:371-382.

Roy, S. 2011. Strategies to improve landscape scale management of mink populations in the west coast of Scotland: lessons learned from the uists 2001-2006. Pp. 114-117 in: Veitch, CR; MN Clout \& DR Towns (eds.). Island invasives: eradication and management. IUCN, Gland.

VALENZUELA 2011. Ecología y distribución del visón americano (Neovisonvison) en Tierra del Fuego: efectos de este predador exótico en la fauna nativa.Ph.D. Thesis, Buenos Aires University.

Valenzuela, AEJ; A Raya Rey; L Fasola \& A Schiavini. 2013. Understanding the inter-specific dynamics of two co-existing predators in the Tierra del Fuego Archipelago: the native southern river otter and the exotic American mink. Biol. Invasions, 15:645-656.

Yamaguchi, N \& DW MacDonald. 2003. The Burden of Co-Occupancy: Intraspecific Resource Competition and Spacing Patterns in American Mink, Mustela Vison. J. Mammal., 84:1341-1355.

Zabala, J; I Zuberogoitia \& JA GonZÁlez-Oreja. 2010. "Estimating costs and outcomes of invasive American mink (Neovison vison) management in continental areas: a framework for evidence based control and eradication. Biol. Invasions, 12:2999-3012. 